\title{
Acute lung function response to cotton dust in atopic and non-atopic individuals
}

\author{
M-J SEPULVEDA, ' R M CASTELLAN, ' J L HANKINSON, ${ }^{1}$ AND J B COCKE² \\ From the Division of Respiratory Disease Studies, ${ }^{1}$ National Institute for Occupational Safety and Health \\ (NIOSH), Morgantown, WV, and Cotton Quality Research Station, ${ }^{2}$ US Department of Agriculture, \\ Clemson, South Carolina, USA
}

ABSTRACT Acute spirometric responses to inhaled cotton dust were examined in a population of 226 healthy, non-asthmatic adults whose atopic status had been evaluated by skin prick tests to 10 common environmental allergens. Exposure to cotton dust occurred in model cardrooms where elutriated dust levels were carefully controlled $\left(1.02 \mathrm{mg} / \mathrm{m}^{3}\right)$. Atopy, defined as positive prick tests to at least two allergens, was observed in $26 \%$ of subjects. Significant forced expiratory volume in one second $\left(\mathrm{FEV}_{1}\right)$ decrements occurred after exposure to cotton dust independent of atopic status $(\mathrm{p}<0.001)$. The mean $\mathrm{FEV}_{1}$ decline in atopic subjects, however, was significantly greater than in non-atopic subjects $(p<0.05)$. Degree of atopy, as measured by number of positive skin tests, also exhibited a significant association with cotton induced decrements in $\mathrm{FEV}_{1}(\mathrm{p}<0 \cdot 05)$. These data suggest that atopy may be an important determinant of the magnitude of the acute pulmonary response to cotton dust. This may reflect the non-specific airways hyperresponsiveness that has been described in non-asthmatic, atopic individuals.

Acute decrements in lung function have been observed in cotton textile workers and in previously unexposed individuals after exposure to cotton dust. ${ }^{2}$ This response has been related to concentrations of total and respirable dust, and to grade, microbial, and endotoxin content of cotton. ${ }^{3-6}$ The precise role of the atopic state in acute pulmonary responses to cotton dust is the subject of considerable speculation but may be of great importance if acute declines in lung function are found to be related to the chronic respiratory disease described in cotton textile workers. ${ }^{78}$

During the course of selecting volunteer subjects for a study of the pulmonary effects of dust from pretreated cotton, atopic status was evaluated by performing prick tests to common inhalant allergens. Skin tests were used to examine the relation between atopy and acute spirometric responses to controlled concentrations of untreated cotton dust. We report here the results of this investigation.

Received 20 June 1983

Accepted 17 October 1983

Mention of product names does not constitute endorsement by NIOSH.
STUDY PROTOCOL

Adult volunteer subjects, obtained from a South Carolina community, provided informed consent and were screened to exclude those with a forced expiratory volume in one second $\left(\mathrm{FEV}_{1}\right)$ below $80 \%$ of predicted, those currently employed as cotton textile workers, and those with a history of asthma, chronic bronchitis, use of medications affecting airway tone, significant heart disease, or any other medical condition precluding safe participation in an exposure study. ${ }^{\text {The }}$ Themaining healthy subjects then underwent skin testing and two separate six hour exposures each to no dust and to a controlled concentration of cotton dust. Each exposure was separated by at least two full days and alternated a control (no cotton dust) and cotton dust exposure. All exposures occurred at the same time of day.

Allergy skin testing used diluent (50\% glycerin) and histamine $(1 \mathrm{mg} / \mathrm{ml}$ histamine base) controls, and 10 common South Carolina aeroallergens, ${ }^{10}$ including pollens (grasses, weeds, trees), Alternaria tenuis, house dust, and mite. Extract concentrations were 1:20 weight/volume except for house dust $(1: 10 \mathrm{w} / \mathrm{v})$ and mite $(1: 50 \mathrm{w} / \mathrm{v})$. To avoid drug interference with the test responses, the participants were instructed not to use antihistamine containing preparations for five days before testing. " Prick 
tests were performed on the volar surface of the forearm by standard methods, ${ }^{12}$ and positive immediate reactions were defined as weals at least 3 $\mathrm{mm}$ in diameter in the presence of negative diluent and positive histamine control reactions. Atopy was defined as a positive reaction to two or more allergen extracts.

Spirometry conformed to criteria recommended by the American Thoracic Society ${ }^{13}$ and was performed using the same technician and instrument immediately before and after six hours of each exposure. The spirometer used was a dry rolling seal spirometer (Ohio Medical Products 840) directly interfaced with an oscilloscope and computer (Digital LSI 11/23). The subjects performed at least five maximal forced expiratory manoeuvres at each test period, and the largest $\mathrm{FEV}_{1}$ and forced vital capacity (FVC) were selected for analysis regardless of the curve(s) on which they occurred. Flow volume curves were aligned at total lung capacity and maximum expiratory flow rates were obtained from the resulting maximum envelopes. The predicted values for FEV ${ }_{1}$ and FVC used were those of Knudson et al,,$^{14}$ corrected by a factor of 0.85 for blacks.

Exposures to cotton dust occurred in identical model cardrooms and used the same blended, strict low middling cotton. Carding was performed at a constant rate, and dust concentrations were controlled by varying the amount of ventilation. Dust levels were monitored in each room with four vertical elutriators, one in each quadrant of the room. Gravimetric analysis of elutriator filters was done hourly, and appropriate ventilation adjustments were made to maintain the desired concentration of cotton dust $\left(1 \mathrm{mg} / \mathrm{m}^{3}\right)$. The subjects sat in chairs placed around the carding machine and were moved on a regular basis so that they made a complete circuit during the exposure period. Control exposures (no cotton dust) took place in two rooms ventilated with fresh air in an adjacent building; dust monitoring was performed in an identical fashion during these exposures. Smoking was not permitted during exposures and subjects were allowed to leave the rooms only for brief restroom breaks.

STATISTICAL ANALYSIS

Acute lung function responses were assessed by determining percentage change $(\% \Delta)$ over each exposure as follows: postexposure value minus preexposure value/pre-exposure value $\times 100$. Negative percentage changes indicate, therefore, an exposure related decrement. Means were obtained from the two control and two cotton dust exposures and were used to calculate a change relative to the control exposure, $\Delta \% \Delta=\% \Delta$ cotton exposure less $\% \Delta$ control exposure.
Table 1 Demographic features and baseline lung function of the study group by atopic status

\begin{tabular}{|c|c|c|c|}
\hline & Atopic & Non-atopic & Total \\
\hline $\begin{array}{l}\text { No }(\% \text { total }) \\
\text { Mean age }(\mathrm{SE})\end{array}$ & $\begin{array}{l}59(26) \\
28(1)\end{array}$ & $\begin{array}{r}167(74) \\
30(1)\end{array}$ & $\begin{array}{r}226(100) \\
29(1)\end{array}$ \\
\hline $\begin{array}{l}\text { Sex: } \\
\quad \text { Female (\%) }\end{array}$ & 54 & 62 & 60 \\
\hline Race: & 64 & 78 & 75 \\
\hline $\begin{array}{l}\text { Smoking: } \\
\text { Current smoker }(\%) \\
\text { Never smoked }(\%) \\
\text { Mean pack years }(\mathrm{SE}) \\
\text { Mean dust level }\left(\mathrm{mg} / \mathrm{m}^{3}\right)\end{array}$ & $\begin{array}{l}45 \\
47 \\
2 \cdot 8(0 \cdot 6)^{*}\end{array}$ & $\begin{array}{l}41 \\
45 \\
5 \cdot 6(0 \cdot 9)^{*}\end{array}$ & $\begin{array}{l}42 \\
\quad 46 \\
4 \cdot 9(0 \cdot 9)\end{array}$ \\
\hline $\begin{array}{l}\text { Control (SEM) } \\
\text { Cotton (SEM) }\end{array}$ & $\begin{array}{l}0.04\left(\begin{array}{l}0.01) \\
1.02 \\
0.01)\end{array}\right.\end{array}$ & $\begin{array}{l}0.04(0-01) \\
1.02(0-01)\end{array}$ & $\left\{\begin{array}{l}0.04(0.01) \\
1.02(0.01)\end{array}\right.$ \\
\hline $\begin{array}{l}\text { Cotton mill work: } \\
\text { Subjects with (\%) } \\
\text { Mean years (SE) }\end{array}$ & 34 & $\begin{array}{l}49 \\
1.7(0 \cdot 2)^{*}\end{array}$ & ${ }^{*} \stackrel{45}{1.5(0.2)}$ \\
\hline $\begin{array}{l}\text { Baseline lung function: } \\
\text { Pred FEV } \\
\text { Pred FVC (SE) (\%) } \\
\text { Pred }^{(}(\%)\end{array}$ & $\begin{array}{l}94(2) \\
97(2)\end{array}$ & $\begin{array}{r}96(1) \\
100(1)\end{array}$ & $\begin{array}{r}96(1) \\
100(1)\end{array}$ \\
\hline
\end{tabular}

${ }^{*} \mathrm{p}<0.01$, two tailed $t$ test.

Differences in acute responses between atopic and non-atopic subjects were compared by two tailed $t$ tests. Linear modelling was used to evaluate the relation between acute changes in lung function and years of cotton mill work, pack-years of smoking, atopic status (atopics $v$ non-atopic), and number of postive skin tests. ${ }^{15}$

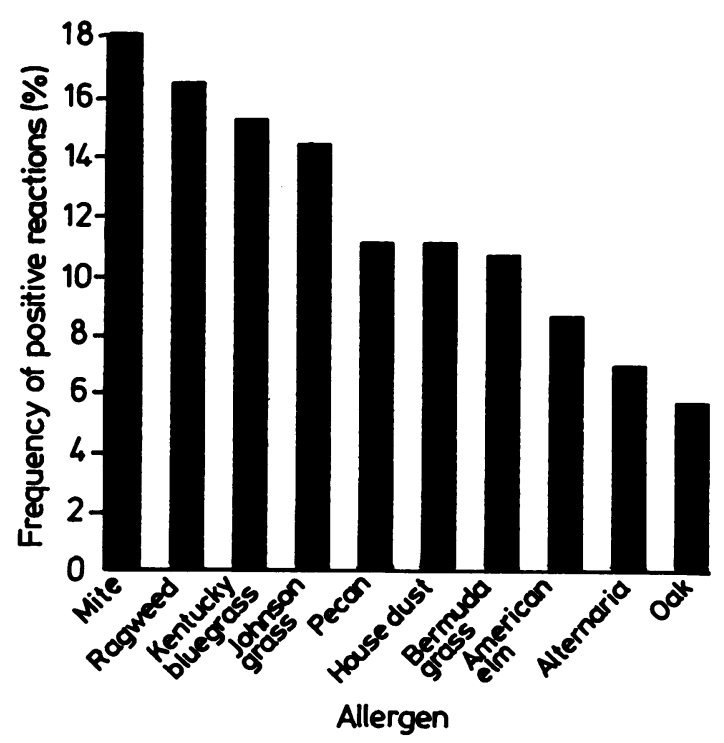

Fig 1 Frequency distribution showing percentage of total population $(n=226)$ with a positive reaction to each allergen. 


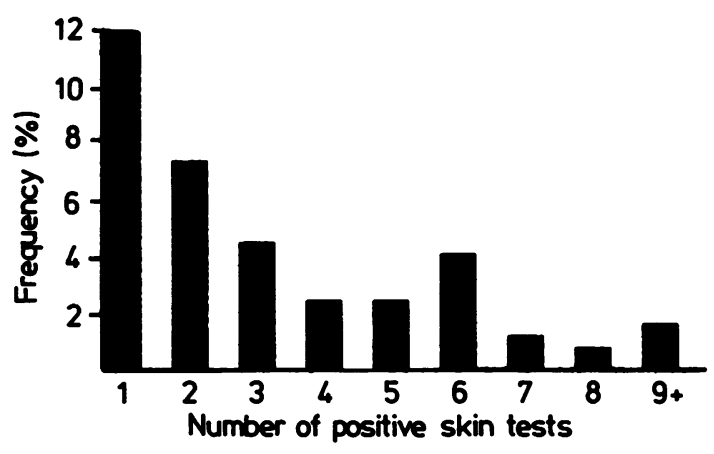

Fig 2 Histogram showing proportions of population ( $n=$ 226) with specified number of positive skin tests.

\section{Results}

Table 1 shows the demographic profile and baseline lung function of the study group. The population as a whole was predominantly white, contained slightly more women than men, and had a mean age of 29 . Current and never cigarette smokers comprised about equal proportions of the study group, and the actual mean level of exposure to cotton dust $( \pm$ SEM) was $1.02 \pm 0.01 \mathrm{mg} / \mathrm{m}^{3}$. Twenty six percent of subjects were atopic by prick testing of the skin and were similar to non-atopic individuals in all respects except pack-years of smoking and previous exposure to cotton dust. Pack-years of smoking and cumulative years of cotton mill work, however, were few in both groups.

The prevalence rates of cutaneous hypersensitivity to allergens used are illustrated in fig 1 . Mite, ragweed, and Kentucky blue grass showed the highest rates of reactivity. Twelve percent of participants had a positive reaction to one allergen, about $8 \%$ to two allergens, and $18 \%$ to three or more allergens (fig 2).

The acute lung function response to inhaled cotton dust was evaluated by comparing mean changes on the days of exposure to cotton dust with mean changes during the control exposures. Table 2 shows

Table 2 Lung function response to inhaled cotton dust by atopic status

\begin{tabular}{|c|c|c|c|}
\hline & $\begin{array}{l}\text { Atopic } \\
(n=59)\end{array}$ & $\begin{array}{l}\text { Non-atopic } \\
(n=167)\end{array}$ & $p$ value $\dagger$ \\
\hline $\begin{array}{l}\Delta \% \Delta^{*}(\mathrm{SE}): \\
\text { FEV } \\
\text { FVC } \\
\text { PFR } \\
\text { FEF }_{\mathbf{5 0}} \\
\text { FEF }_{75}\end{array}$ & $\begin{array}{r}-6.9(0.9) \\
-3.9(0.7) \\
-6.3(1.3) \\
-17.1(2.4) \\
-28.7(3.7)\end{array}$ & $\begin{array}{r}-4 \cdot 6(0 \cdot 3) \\
-3 \cdot 0(0 \cdot 3) \\
-3 \cdot 6(0.5) \\
-12.9(1 \cdot 1) \\
-23 \cdot 1(1 \cdot 6)\end{array}$ & $\begin{array}{l}0.04 \\
0.23 \\
0.07 \\
0.12 \\
0.17 \\
\end{array}$ \\
\hline
\end{tabular}

${ }^{*} \Delta \% \Delta$ is the mean $\%$ change during cotton dust exposures less the mean $\%$ change during the control exposures.

$\left\lceil\right.$ Two tailed $t$ test; $\mathrm{H}_{0}: \Delta \% \Delta$ atopic $=\Delta \% \Delta$ non-atopic. the differences between these means by atopic status. Significant exposure related decrements occurred in all spirometric indices independent of atopic status $(\mathrm{p}<0.001)$. While cotton induced decrements were generally greater in atopics compared with non-atopics, only the $\mathrm{FEV}_{1}$ response was observed to be significantly different between the two groups $(p=0 \cdot 04)$.

To assess the effect of pack-years of smoking, years of cotton textile work, atopic status, and number of positive skin responses to acute changes in lung function, linear models using these as independent variables were used. Pack-years of smoking and years of cotton mill work were not found to be related to acute changes in pulmonary function. Atopic status and number of positive skin tests were associated with greater acute declines in $\operatorname{FEV}_{1}(\mathrm{p}<$ $0 \cdot 05)$.

To evaluate further the relation between lung function responses and atopic status, the distributions of percentage change in $\mathrm{FEV}_{1}$ were examined for the group of atopic subjects $(n=59)$ and for the group of non-atopic individuals $(n=167)$ (fig 3$)$. Non-atopic participants showed an approximately normal distribution with a mean percentage $\mathrm{FEV}_{1}$ change of $-4.6 \%$ relative to the mean control exposure response (table 2). By contrast, the atopic group had a distribution with a mean percentage FEV $_{1}$ change of $-6.9 \%$ and a skewness towards larger $\mathrm{FEV}_{1}$ decrements.

\section{Conclusions}

Atopy has been defined as "that form of immunological reactivity of the subject in which

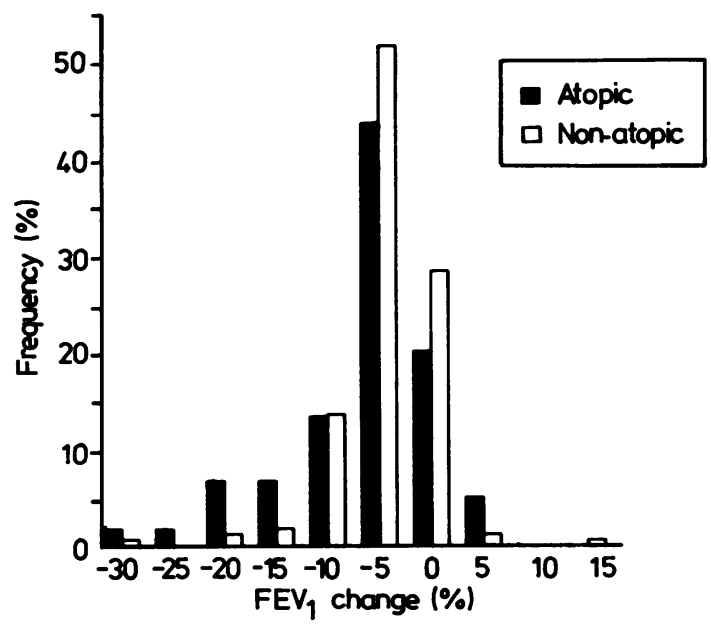

Fig 3 Distribution of acute $F E V_{1}$ responses to inhaled cotton dust (relative to control exposures) by atopic status. 
reaginic antibody, now identifiable as IgE antibody, is readily produced in response to ordinary exposure to the common allergens of the subject's environment." ${ }^{16}$ It may be assessed by allergen specific prick tests of the skin that have proved to be reliable and sensitive indicators of immunoglobulin sensitised mast cells. ${ }^{12}$ Atopy has been observed to play a prominent part in allergic diseases (extrinsic asthma, allergic rhinitis, atopic dermatitis), ${ }^{17}$ and has also proved useful in the identification of individuals at increased risk of sensitisation to occupational allergens. ${ }^{18}$

The demonstration of airway hyperresponsiveness in people with bronchial asthma has also stimulated inquiry into this condition in the airways of nonasthmatic atopic individuals. Studies by Townley $e t$ $a l^{19}$ and Fish et $a l^{20}$ have shown that non-asthmatic atopic individuals may show enhanced airway responsiveness when challenged with the cholinergic agent, methacholine. The question of whether atopic subjects respond differently from non-atopic subjects to bronchoactive occupational dusts has therefore become important.

The relation between acute lung function response in cotton dust exposed subjects and atopic status has been examined in only one epidemiological investigation. Jones and his colleagues examined workers in several cottonseed crushing mills with respiratory questionnaires, shift spirometry, and skin prick tests to 10 common inhalant allergens. ${ }^{21}$ They observed significantly greater $\mathrm{FEV}_{1}$ declines over the work shift in atopic workers exposed to linter dust than in their non-atopic counterparts. This differential response could not be ascribed to differences in demographic profiles, smoking habit, or dust levels.

The current study confirms and extends these findings. Our population was selected to exclude known asthmatics, chronic bronchitics, current cotton textile workers, and people with an abnormal baseline $F E V_{1}$. Yet the prevalence rate of a single positive skin test observed in our study group (35\%) was similar to that reported in other populations by Barbee et al (34\%) and Curran and Goldman $(28.9 \%) .^{22}{ }^{23}$ Using the same definition of atopy as Jones $e t a l, 21$ we also found significantly greater acute declines in pulmonary function in atopics than in non-atopics after exposure to cotton dust.

The cotton induced acute decrements in lung function showed two additional features in our study. Analysis of covariance indicated that, among those with positive skin tests, the greater the number of positive tests, the larger the acute decline in pulmonary function. A comparison of the distributions

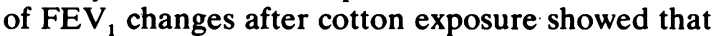
atopic individuals contributed disproportionately to the group with the larger $\mathrm{FEV}_{1}$ decrements (fig 3). These data suggest that the degree of atopy may define a subgroup of atopic subjects who are particularly susceptible to the acute bronchoconstrictor effect of cotton dust.

Type I (IgE-mediated) immune reactions have not been shown to have a causal role in the acute pulmonary response to cotton dust. ${ }^{24-26}$ In addition, immediate hypersensitivity to common inhalant allergens is not required for the acute lung function response to cotton dust (table 2). The present study and that of Jones et al, ${ }^{21}$ however, indicate that atopy is an important determinant of the degree of acute bronchoconstriction induced by cotton dust and linter dust, respectively. Probably, therefore, atopy acts as a marker for non-specific bronchial hyperresponsiveness, ${ }^{19}$ and the latter is responsible for the greater effect among atopic individuals.

We thank Dr L Blair Thrush, Dr Alan D Engelberg, and Betsy Post for their thoughtful help during the course of this study.

Requests for reprints to: M-J Sepulveda, MD, Clinical Investigations Branch, National Institute for Occupational Safety and Health, 944 Chestnut Ridge Road, Morgantown, WV 26505, USA.

\section{References}

' McKerrow CB, Molyneux MKB. The influence of previous dust exposure on the acute respiratory effects of cotton dust inhalation. Proceedings of the 2 nd international conference on respiratory diseases in textile workers, Alicante, Spain. 1968:95-101.

${ }^{2}$ Berry G, McKerrow CB, Molyneux MKB, Rossiter CE, Tombleson JBL. A study of acute and chronic changes in ventilatory capacity of workers in the Lancashire cotton mills. $\mathrm{Br} \mathbf{J}$ Ind Med 1973;30:25-36.

${ }^{3}$ Berry G, Molyneux MKB. The correlation of cotton dust exposure and physiological response. Proceedings of the 2 nd international conference on respiratory diseases in textile workers, Alicante, Spain. 1968:184-7.

${ }^{4}$ Merchant JA, Lumsden JC, Kilburn KH, et al. Dose response studies in cotton textile workers. JOM 1973;15:222-30.

${ }^{5}$ Rylander R, Imbus HR, Suh MW. Bacterial contamination of cotton as an indicator of respiratory effects among card room workers. Br J Ind Med 1979;36:299-304.

' Olenchock SA, Castellan RM, Cocke JP, Rodak DJ, Hankinson JL, Mull JC. Endotoxins and acute pulmonary function changes during cotton dust exposures. In: Wakelyn PJ, Jacobs RR, eds. Proceedings of the 7th cotton dust research conference. Beltwide cotton production research conferences. San Antonio, Texas: National Cotton Council and the Cotton Foundation. 1983:70-2.

' Schilling RSF, Hughes JPW, Dingwall-Fordyce I, Gilson JC. An epidemiological study of byssinosis among Lancashire cotton workers. Br J Ind Med 1955; 12:217-27.

${ }^{8}$ El-Sadik YM, Mobelhi M, El-Hinady AR, Mostafa MN. Study of lung function changes among different grades of byssinosis. $\mathrm{Br}$ $J$ Ind Med 1972;29:184-7.

9 Cocke JB, Castellan RM, Hankinson JL, Sasser PE. Pulmonary function response to washed and unwashed cotton. In: Wakelyn PJ, Jacobs RR, eds. Proceedings of the 7th cotton dust 
research conference. Beltwide cotton production research conferences. San Antonio, Texas: National Cotton Council and the Cotton Foundation, 1983:62-6.

" Chang WWY. Pollen survey of the United States. In: Patterson $\mathrm{R}$, ed. Allergic diseases: diagnosis and management. Philadelphia: JB Lippincott Company, 1980:161.

"Galant SP, Bullock J, Wong D, Maibach HI. The inhibitory effect of antiallergy drugs on allergen and histamine induced wheal and flare responses. J Allergy Clin Immunol 1973;51:11-21.

${ }^{12}$ Pepys J. Skin testing. Br J Hosp Med 1975; 14:412-7.

${ }^{13}$ American Thoracic Society. Standardization of spirometry. Am Rev Respir Dis 1979;119:831-8.

${ }^{14}$ Knudson RJ, Slatin RC, Lebowitz MD, Burrows B. The maximal expiratory flow-volume curve: normal standards, variability, effects of age. Am Rev Respir Dis 1976; 113:587-600.

is Draper NR, Smith H. Applied regression analysis. New York: John Wiley and Sons, 1966.

${ }^{16}$ Pepys J. Skin tests in diagnosis. In: Gell PGH, Coombs RRA, Lachmann PJ, eds. Clinical aspects of immunology. Oxford: Blackwell Scientific, 1975:879.

${ }^{17}$ Smith JM. Epidemiology and natural history of asthma, allergic rhinitis, and atopic dermatitis (eczema). In: Middleton EJR, Reed CE, Ellis EF, eds. Allergy: principles and practice. St Louis: CV Mosby Co, 1978:633-58.

${ }^{18}$ Greenberg M, Milne JF, Watt A. Survey of workers exposed to dusts containing derivatives of Bacillus subtilis. $\mathrm{Br}$ Med $\mathrm{J}$ 1970;ii:629-33.

${ }^{19}$ Townley RG, Ryo UY, Kolotkin BM, Kang B. Bronchial sen- sitivity to methacholine in current and former asthmatic and allergic rhinitis patients and control subjects. J Allergy Clin Immunol 1975; 56:429-42.

${ }^{20}$ Fish JE, Rosenthal RR, Batra G, et al. Airway responses to methacholine in allergic and nonallergic subjects. Am Rev Respir Dis 1976;113:579-86.

2 Jones RN, Butcher BT, Hammad YY, et al. Interaction of atopy and exposure to cotton dust in the bronchoconstrictor response. $\mathrm{Br} \mathrm{J}$ Ind Med 1980;37:141-6.

${ }^{22}$ Barbee RA, Lebowitz MD, Thompson HC, Burrows B. Immediate skin-test reactivity in a general population sample. Ann Intern Med 1976;84:129-33.

${ }^{23}$ Curran WS, Goldman G. The incidence of immediately reacting allergy skin tests in a "normal" adult population. Ann Intern Med 1961;55:777-83.

${ }^{24}$ Cayton HR, Furness G, Maitland HB. Studies on cotton dust in relation to byssinosis. Part II Skin tests for allergy with extracts of cotton dust. $\mathrm{Br} J$ Ind Med 1952;9:186-96.

${ }^{25}$ Popa V, Gavilescu N, Preda N, Teculescu D, Plecias M, Cirstea M. An investigation of allergy in byssinosis: sensitization of cotton, hemp, flax, and jute antigens. $\mathrm{Br} J$ Ind Med 1969;26: 101-8.

${ }^{26}$ Butcher BT, O'Neil CE, Reed MA, Diem JE, Sharon G. Humoral antibody response to cotton dusts. In: Wakelyn PJ, Jacobs RR, eds. Proceedings of the 7th cotton dust research conference. Beltwide cotton production research conferences. San Antonio, Texas: National Cotton Council and the Cotton Foundation, 1983:19-21. 